\title{
Effect of Therapeutic Ultrasound on Human Periodontal Ligament Cells for Dental and Periodontal Tissue Engineering
}

\author{
Tarek El-Bialy ${ }^{\mathrm{a},{ }^{*}}$, Adel Alhadlaq ${ }^{\mathrm{b}}$ and Brian Lam ${ }^{\mathrm{c}}$ \\ ${ }^{a}$ Faculty of Medicine and Dentistry, University of Alberta, Edmonton, Canada \\ ${ }^{b}$ King Saud University, Riyadh, Saudi Arabia \\ ${ }^{c}$ University of Nevada, Las Vegas, NV, USA
}

\begin{abstract}
The objective of this study was to investigate whether low intensity pulsed ultrasound (LIPUS) has anabolic effects on human periodontal ligament (PDL) cells. The PDL cells were plated in 48 -well plates and cultured at $37^{\circ} \mathrm{C}$ in an atmosphere of $5 \% \mathrm{CO}_{2}$ in air, in a humidified incubator until confluent. The cells were divided into three groups including control, $5 \mathrm{~min}$ and $10 \mathrm{~min}$ ultrasound application. The LIPUS was applied using a 2.5 transducer that produces an incident intensity of $30 \mathrm{~mW} / \mathrm{cm}^{2}$ of the transducer's surface area. The results from the quantitative polymerase chain reaction (PCR) indicates that expression levels of alkaline phosphatase (ALP),cyclin D1 (CYC), nucleostemin (NCT) were increased after four weeks of 10 minutes of daily ultrasound treatment. The increased ALP/DNA by LIPUS shows a time dependent pattern with the highest activity occurring after four weeks of treatment. These results demonstrate that LIPUS has an anabolic effect on PDL cells and suggest that LIPUS may enhance the pluripotent characteristics of PDL cells as indicated by the up-regulation of NCT, a stem marker. These results also may explain the potential role of LIPUS in periodontal tissue regeneration.
\end{abstract}

Keywords: LIPUS, PDL, Stem cells, Anabolic effect.

\section{INTRODUCTION}

Dental and periodontal tissue regenerations have recently received a great deal of attention in the literature. Mesenchymal stem cells provide an important component that processes many challenges regarding their source and their potential in dental and/or periodontal tissue engineering. Bone marrow stem cells have the challenge of donor site morbidity due to the frequent surgical intervention required in order to obtain sufficient cell density for dental or periodontal tissue engineering.

Periodontal ligament (PDL) cells are among the main cellular components of the periodontal ligament connective tissue and they are also involved in matrix production [1]. A previous report showed that PDL cells can differentiate into osteoblast-like cells and can be helpful in alveolar bone regeneration [2]. It has been reported that PDL cells can express bone associated molecules and proteins such as alkaline phosphatase (ALP), osteopontin (OPN), and osteocalcin (OCN) $[3,4]$. Consequently, PDL cells have been considered as a promising cell source for potential alveolar bone and or PDL tissue regeneration and engineering $[5,6]$. Recent reports showed that Mesenchymal stem cells can be isolated from PDL and their potential use in dento-facial tissue engineering is promising [7-9]. It has been recently reported that cementoblasts are differentiated from PDL precursor cells

*Address correspondence to this author at the Orthodontics and Biomedical Engineering, Canada; Tel: 780-492-2751; Fax: 780-492-1624;

E-mails: telbialy@ualberta.ca, telbialy@hotmail.com
[10]. Moreover, a recent report showed that dentine can be tissue engineered using PDL stem cells [11]. So it seems that PDL cells could be an alternative source for dental tissue engineering due to their potential of being differentiated into bone or dental tissue producing cells.

Low intensity pulsed ultrasound (LIPUS) is a form of non-invasive mechanical energy that demonstrated anabolic effects on different cells including gingival fibroblasts, [12], cementoblasts [13], PDL and bone cells [14] in vitro. In vivo studies demonstrated the effectiveness of LIPUS at 30 $\mathrm{mW} / \mathrm{cm}^{2}$ intensity to accelerate tooth eruption and dental tissue formation in rabbits [15]; to enhance periodontal wound healing after flap surgery in dogs [16] and to increase cementum and dentine formation in human patients as a defensive mechanism to repair orthodontically induced root resorption [17]. These results were further confirmed by an in-vitro study that showed that LIPUS at $30 \mathrm{~mW} / \mathrm{cm}^{2}$ significantly enhanced cellular proliferation, ALP activity and ColI expression in cementoblasts [18]. The purpose of this study was to determine the effect of LIPUS on the stem cell characteristics.

\section{MATERIALS AND METHODS}

\section{Cell Culture}

The Human PDL cells (CC-7049 HPdLF-Peridon Lig Fibro SCGM, cryo amp) were purchased from Lonza Ltd. (Allendale, NJ, USA). The cells were plated in 48-well plates at a density of $2.5 \times 10^{4}$ cells per $\mathrm{mL}$ of culture media. The media consisted of DMEM with $10 \%$ fetal bovine serum, 100 $\mathrm{U} / \mathrm{mL}$ of penicillin, and $100 \mathrm{U} / \mathrm{mL}$ streptomycin (Invitrogen, 
Burlington, ON, Canada). The cells were then cultured at $37^{\circ} \mathrm{C}$ in an atmosphere of $5 \% \mathrm{CO}^{2}$ in air, in a humidified incubator. Once the cells were confluent they were subjected to (LIPUS) treatment in triplicate.

\section{Ultrasound Application}

The ultrasound device was provided by (SmileSonica, Inc., Edmonton, AB, Canada). The LIPUS was applied using a 2.5 transducer that produces an incident intensity of 30 $\mathrm{mW} / \mathrm{cm}^{2}$ of the transducer's surface area for each sample. During application, the transducer was placed at the bottom on each well and coupled with ultrasound gel. The experimental groups were divided into three groups. Group 1 (control group) and received a sham LIPUS transducer that was not active, group 2 received 5 minutes of daily ultrasound (LIPUS) application and group 3 received 10 minutes of daily LIPUS application. This treatment was performed for a four-week period. LIPUS power was calibrated every week and was checked before each application using a special ultrasound indicator.

\section{Analysis of ALP and DNA Quantification}

ALP activity, which is a membrane bound enzyme, reaches the maximum expression before the beginning of mineralization and is considered an early marker for mineral formation [19]. PDL cells were washed with HBSS and lysed using ALP buffer containing 0.5 M 2-amino-2methylpropan-1-ol and $0.1 \%(\mathrm{v} / \mathrm{v})$ Triton-X100 at $\mathrm{pH} 10.5$. After two hours, $100 \mu \mathrm{L}$ from each lysate was added in duplicates into 96-well plates and a $100 \mu \mathrm{L}$ of $2 \mathrm{mg} / \mathrm{mL}$ ALP substrate p-NPP (p-nitrophenol) was added to the cell lysate. The absorbance of the colored product was then quantified at $405 \mathrm{~nm}$ at periodic intervals for up to 20 minutes. The ALP activity was presented as p-NPP formed for every minute $(\mathrm{mmol} / \mathrm{min} / \mathrm{mL})$, and normalized by the total DNA content ( $\mu \mathrm{g}$ DNA $/ \mathrm{mL}$ ) of each lysate to attain the specific ALP activity (ALP/DNA). DNA concentrations were determined using the CyQUANT DNA kit (Molecular Probes, Portland, OR, USA) according to the manufacturer's instructions [19]. ALP/DNA assay was performed at the end of every week.

\section{QUANTITATIVE POLYMERASE CHAIN REACTION [qPCR]}

Total RNA extraction was isolated using RNeasy Fibrous Tissue Mini Kit (QIAGEN Inc., Valencia, CA, USA) and then reverse transcribed using the SuperScriptTM first-strand synthesis system for RT-PCR (Invitrogen) Life Technologies Inc., Burlington, ON, Canada following the manufacturer's instructions as described previously [20].

The PCR amplifications was performed using real time PCR (7700, Applied Biosystems, Toronto, ON, Canada), according to the manufacturer's instructions. A total volume of $20 \mu \mathrm{l}$ reaction mixture containing $2 \mu \mathrm{l}$ of cDNA sample, $1 \times \mathrm{SYBR} \otimes$ Green master mix (Applied Biosystems), 20 pmol sense and antisense primers was used. Fluorescence signals were checked at the end of elongation phase for each amplification cycle. To confirm the specificity of the reaction, melting point analysis was carried out after the end of the last amplification cycle. Dissociation of the PCR product was carried out at $90^{\circ} \mathrm{C}$ for 1 minute followed by $55^{\circ} \mathrm{C}$ for 1 minute. Also, negative controls were tested with the same amplification procedures in order to eliminate any false positive result. The quantification of gene expression was evaluated using the comparative $\mathrm{C}(\mathrm{T})$ or $2-\Delta \Delta \mathrm{Ct}$ method with glyceraldehyde-3-phosphate dehydrogenase (GAPDH) as the internal reference gene $[21,22]$. ALP was evaluated as an osteogenic marker [12], CYC genes was evaluated as indicators of cell proliferation [23] and NCT was used as a stem cell specific marker. qPCR was carried out at the end of the second, third and fourth week of treatment.

Primers used for these genes are as follows:

ALP:

\begin{tabular}{|l|l|l|l|l|c|}
\hline $\begin{array}{l}\text { Forward } \\
\text { Primer }\end{array}$ & $\begin{array}{l}\text { CGGACAGGAC- } \\
\text { GCACACACT }\end{array}$ & 59 & 63 & 2231 & 2249 \\
\hline $\begin{array}{l}\text { Reverse } \\
\text { Primer }\end{array}$ & $\begin{array}{l}\text { TCCCTTTTAAC- } \\
\text { CAACACCAAAAA }\end{array}$ & 58 & 35 & 2378 & 2356 \\
\hline Probe & TCCAGGACTCGCCAAC & 70 & 59 & 2261 & 2277 \\
\hline
\end{tabular}

CYC

\begin{tabular}{|l|l|l|l|l|l|}
\hline $\begin{array}{l}\text { Forward } \\
\text { Primer }\end{array}$ & $\begin{array}{l}\text { TTCCCTAGCAA-GCT- } \\
\text { GCCAAA }\end{array}$ & 60 & 50 & 3498 & 3517 \\
\hline $\begin{array}{l}\text { Reverse } \\
\text { Primer }\end{array}$ & $\begin{array}{l}\text { TGGACACAGCAGCCC- } \\
\text { TCAA }\end{array}$ & 60 & 58 & 3587 & 3569 \\
\hline Probe & TTAGCTGAGGCGTCCC & 70 & 63 & 3538 & 3553 \\
\hline
\end{tabular}

NCT

\begin{tabular}{|l|l|l|l|l|l|}
\hline $\begin{array}{l}\text { Forward } \\
\text { Primer }\end{array}$ & $\begin{array}{l}\text { ATCACAATCATAGTA- } \\
\text { GTCCGTGCTT }\end{array}$ & 85 & 38 & 937 & 362 \\
\hline $\begin{array}{l}\text { Reverse } \\
\text { Primer }\end{array}$ & $\begin{array}{l}\text { TGGACTTCGGAGGGCA- } \\
\text { AGT }\end{array}$ & 59 & 58 & 1011 & 993 \\
\hline Probe & $\begin{array}{l}\text { TCACCTTGTAACTCCCC- } \\
\text { TG }\end{array}$ & 69 & 53 & 970 & 988 \\
\hline
\end{tabular}

\section{STATISTICAL ANALYSIS}

All assays were performed in triplicate for each treatment at each time point. Data were analyzed with one-way analysis of variance (ANOVA) using SPSS version 12.0 software package (SPSS, IBM, Armonk, NY, USA). Intergroup differences were determined using the Bonferroni post-hoc test, and statistical significance was defined by p-values $<0.05$.

\section{RESULTS}

ALP/DNA activity was increased after weeks 3 and 4 with a greater increase in the 10 minutes of daily ultrasound application group (Fig. 1). This increase may indicate that the ALP activity is LIPUS treatment dose-dependent. The increase in ALP gene expression was particularly evident after 4 weeks of application with a daily dose of 10 minutes (Fig. 2).

Expression of CYC increased significantly after 4 weeks of 10 minutes of daily doses of ultrasound (Fig. 3). There was also an increase in the 5 minute group after 4 weeks. This was compared to the other groups after weeks 2 to 3 . The expression of NCT followed a similar trend (Fig. 4).

\section{DISCUSSION}

In dental tissue engineering, Mesenchymal stem cells are always needed to make up the bulk of the engineered tissue, or 


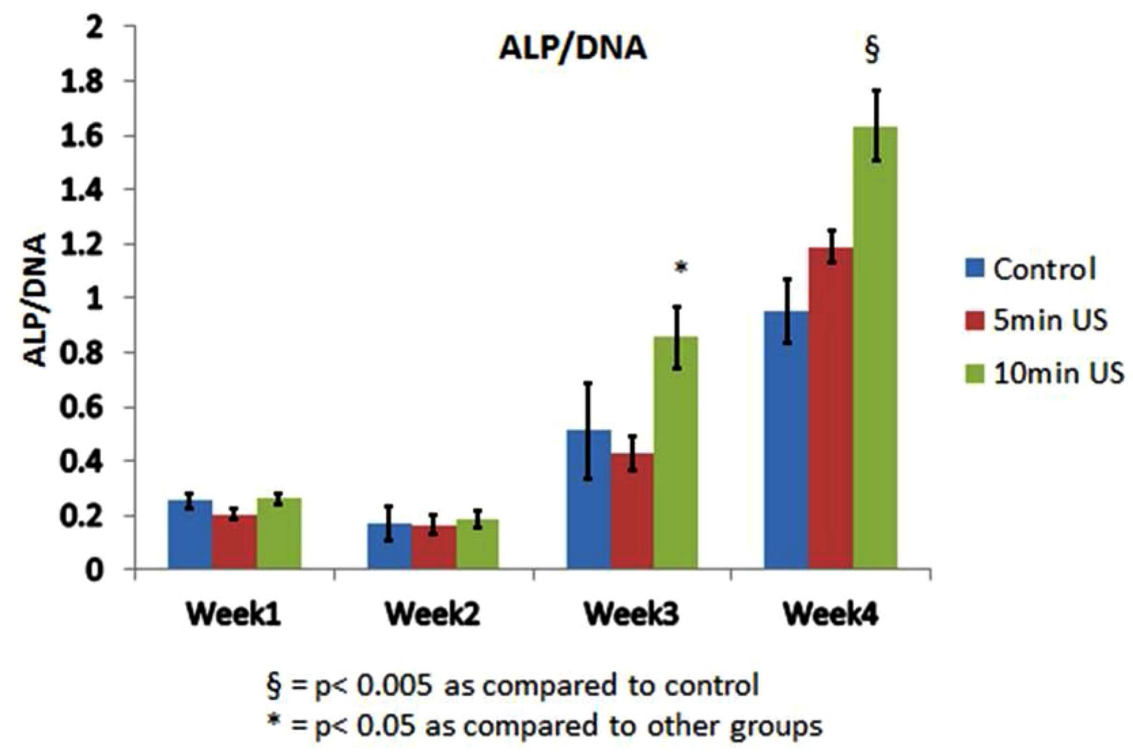

Fig. (1). ALP/DNA activity in all groups.

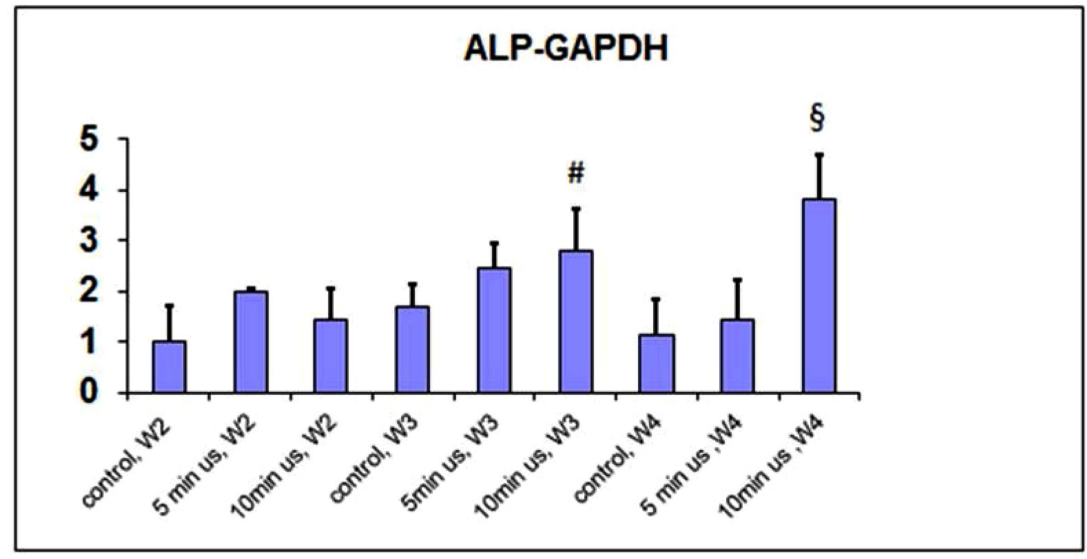

$$
\begin{aligned}
& \#=p<0.05 \text { as compared to the control } \\
& \S=p<0.005 \text { as compared to groups }
\end{aligned}
$$

Fig. (2). qPCR of the ALP gene normalized to GAPDH.

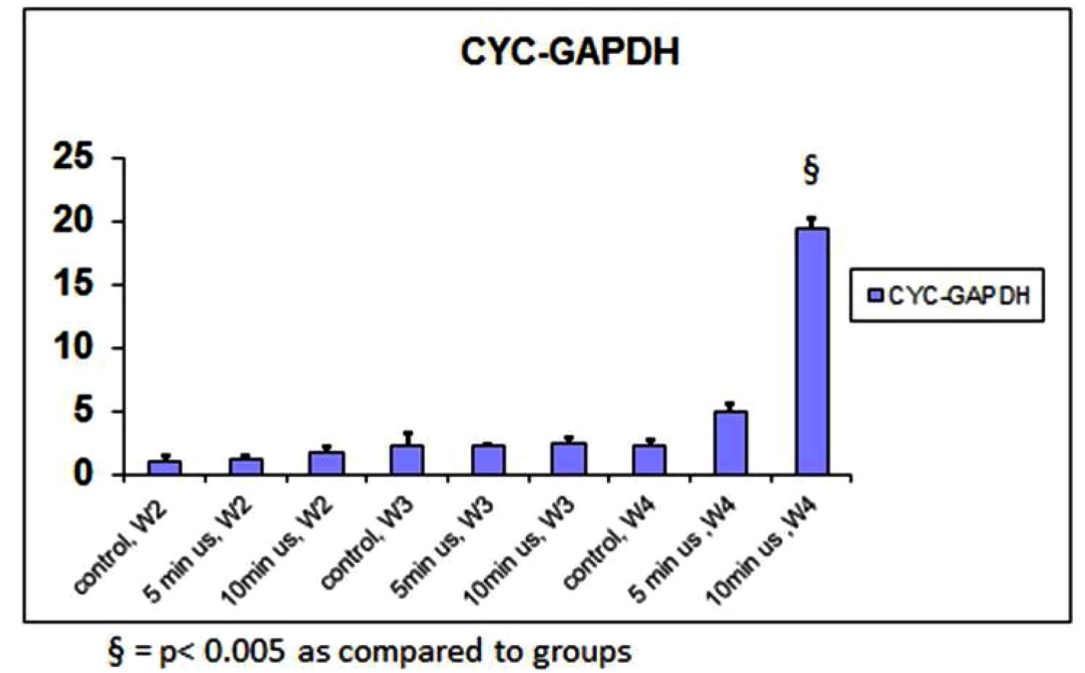

Fig. (3). qPCR of CYC gene normalized to GAPDH. 


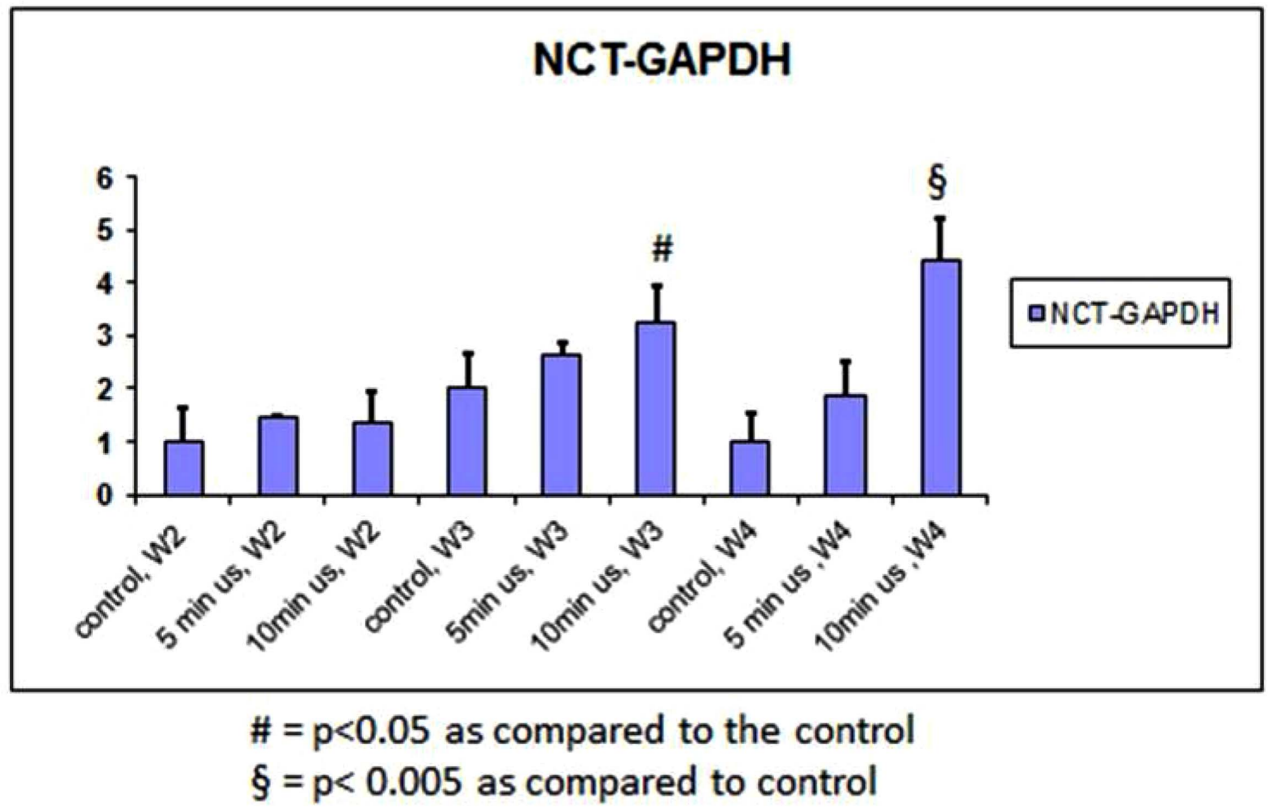

Fig. (4). qPCR of the NCT gene normalized to GAPDH.

tooth parts. To engineer a tooth or tooth part, a scaffold, cells and conditioning growth factors are needed. In addition, cementoblasts or cementobalst like cells are needed to form a cementum layer on top of the engineered dentin bulk of the root.

ALP was measured in reference to total DNA concentrations of the cells. This provides information about cell activity and is an indicator of mineralization. The results of both ALP/DNA and qPCR indicate that LIPUS increases the mineralization potential of PDL cells when cultured in basic medium. The increase in ALP/DNA by 10 minutes of daily LIPUS application was statistically more significant than both the control and the 5 minutes of daily LIPUS application group after weeks 3 and 4 . This was confirmed by the statistically significant increase in ALP gene expression after four weeks in group 3 that was treated by 10 minutes of LIPUS daily than other groups. This is in agreement with a previous report that showed LIPUS increases ALP activity in the third and fourth week in human gingival fibroblasts [12]. In comparison to our results, Harle, et al., 2001 reported that a single treatment of PDL cells with $3 \mathrm{MHz}$ continuous ultrasound of different power output $(125,250,500$ and 1000 $\mathrm{mW} / \mathrm{cm}^{2}$ ) for five minutes led to up-regulation of different bone morphogenetic proteins like OPN, bone sialoprotein (BSP)[14]. They also reported that the up-regulation of these genes is dose (ultrasound power) dependent. Although they did not report on ALP activity and they used a different ultrasound setting (continuous versus pulsed) than we used and although they used higher ultrasound power than what we used $\left(30 \mathrm{~mW} / \mathrm{cm}^{2}\right)$; there seems to be a trend that ultrasound upregulates mineralized tissue specific genes in PDL cells.

CYC is an indicator of cell proliferation [24]. Our results showed that this gene is up-regulated by LIPUS after four weeks of daily 10 minutes application, and this change is statistically significant compared to the other groups. This is in agreement with a previous report that showed that LIPUS has an anabolic effect on gingival fibroblast cells and this anabolic effect is consistent over four weeks [12].

NCT is a specific marker of stem cells [24]. Our results showed that LIPUS up-regulates NCT expression in PDL cells with 10 minutes of daily application and this stimulatory effect is statistically significant at weeks 3 and 4. After the first two weeks, there is no significant difference between ALP/DNA activity, ALP, CYC or NCT gene expressions. After week 2, ALP gene expression was higher in the group of 5 minutes of daily LIPUS compared to other groups, but this increase was not statistically significant.

Based on the results of this work, we can hypothesize that although PDL cells are scanty in number regardless of their origin, LIPUS may enhance expansion of these cells as indicated by the up-regulation of the CYC gene while maintaining their stem cell characteristics. Future research can be directed towards possibly using PDL cells and LIPUS in dental/periodontal tissue engineering.

\section{CONFLICT OF INTEREST}

The authors confirm that this article content has no conflicts of interest.

\section{ACKNOWLEDGEMENT}

The Authors would like to thank Hamid Sadeghi for his technical support.

\section{REFERENCES}

[1] Nanci A, Bosshardt DD. Structure of periodontal tissues in health and disease. Periodontol 2006; 40: 11-28.

[2] Shimabukuro Y, Ichikawa T, Takayama S, et al. Fibroblast growth factor-2 regulates the synthesis of hyaluronan by human periodontal ligament cells. J Cell Physiol 2005; 203: 557-63.

[3] Lallier TE, Spencer A, Fowler MM. Transcript profiling of periodontal fibroblasts and osteoblasts. J Periodontol 2005; 76: 1044-55.

[4] Ivanovski S, Li H, Haase HR, Bartold PM. Expression of bone associated macromolecules by gingival and periodontal ligament fibroblasts. J Periodontal Res 2001; 36: 131-41. 
[5] Isaka J, Ohazama A, Kobayashi M, et al., Participation of periodontal ligament cells with regeneration of alveolar bone. J Periodontol 2001; 72(3): 314-23.

[6] Benatti BB, Silverio KG, Casati MZ, Sallum EA, Nociti FH, Jr. Physiological features of periodontal regeneration and approaches for periodontal tissue engineering utilizing periodontal ligament cells. J Biosci Bioeng 2007; 103:1-6.

[7] Wang L, Shen H, Zheng W, et al. Characterization of stem cells from alveolar periodontal ligament. Tissue Eng Part A. 2011; 17(78): $1015-26$

[8] Wada N, Wang B, Lin NH, Laslett AL, Gronthos S, Bartold PM. Induced pluripotent stem cell lines derived from human gingival fibroblasts and periodontal ligament fibroblasts. J Periodontal Res 2011; 46(4): 438-47.

[9] Rodríguez-Lozano FJ, Bueno C, Insausti CL, et al. Mesenchymal stem cells derived from dental tissues. Int Endod J 2011; 44(9): 800-6.

[10] Kémoun P, Gronthos S, Snead ML, et al. The role of cell surface markers and enamel matrix derivatives on human periodontal ligament mesenchymal progenitor responses in vitro. Biomaterials 2011. [Epub ahead of print]

[11] Galler KM, Cavender AC, Koeklue U, Suggs LJ, Schmalz G, D'Souza RN. Bioengineering of dental stem cells in a PEGylated fibrin gel. Regen Med 2011; 6(2):191-200.

[12] Mostafa NZ, Uludag H, Dederich DN, Doschak MR, El-Bialy TH. Anabolic effects of low intensity pulsed ultrasound on gingival fibroblasts, Arch Oral Biol 2009; 54 (8): 743-8.

[13] Dalla-Bona DA, Tanaka E, Inubushi T, et al. Cementoblast response to low- and high-intensity ultrasound. Arch Oral Biol 2008; 53(4): 318-23.

[14] Harle J, Salih V, Mayia F, Knowles JC, Olsen I. Effects of ultrasound on the growth and function of bone and periodontal ligament cells in vitro. Ultrasound Med Biol 2001; 27(4): 579-86.
[15] El-Bialy TH, Zaki AE, Evans CA. Effect of ultrasound on rabbit mandibular incisor formation and eruption after mandibular osteodistraction. Am J Orthod Dentofacial Orthop 2003; (124): 427-34.

[16] Ikai H, Tamura T, Watanabe T, et al. Low-intensity pulsed ultrasound accelerates periodontal wound healing after flap surgery. $\mathrm{J}$ Periodontal Res 2008; 43(2): 212-6.

[17] El-Bialy T, El-Shamy I, Graber TM. Repair of orthodontically induced root resorption by ultrasound in humans. Am J Orthod Dentofacial Orthop 2004; 126(2): 186-93.

[18] Inubushi T, Tanaka E, Rego EB, et al. Effects of ultrasound on the proliferation and differentiation of cementoblast lineage cells. J Periodontol 2008; 79(10): 1984-90.

[19] Anderson HC. Mechanism of mineral formation in bone. Lab Invest $1989 ; 60(3): 320-30$.

[20] Varkey M, Kucharski C, Doschak MR, et al. Osteogenic response of bone marrow stromal cells from normal and ovariectomized rats treated with a low dose of basic fibroblast growth factor. Tissue Eng 2007; 13(4): 809-17.

[21] Sciore P, Boykiw R, Hart DA. Semiquantitative reverse transcription-polymerase chain reaction analysis of mRNA for growth factors and growth factor receptors from normal and healing rabbit medial collateral ligament tissue. J Orthop Res 1998; 16: 429-37.

[22] Schmittgen TD, Livak KJ. Analyzing real-time PCR data by the comparative C(T) method. Nat Protoc 2008; 3(6): 1101-8.

[23] Livak KJ, Schmittgen TD. Analysis of relative gene expression data using real-time quantitative PCR and the 2(-Delta Delta C(T)) Method. Methods 2001; 25(4): 402-8.

[24] Yaghoobi MM, Mowla SJ, Tiraihi T. Nucleostemin, a coordinator of self-renewal, is expressed in rat marrow stromal cells and turns off after induction of neural differentiation. Neurosci Lett 2005; 390: 81-6.

Received: July 05, 2012

Revised: August 10, 2012

Accepted: September 27, 2012

(C) El-Bialy et al.; Licensee Bentham Open.

This is an open access article licensed under the terms of the Creative Commons Attribution Non-Commercial License (http://creativecommons.org/licenses/by-nc/3.0/) which permits unrestricted, non-commercial use, distribution and reproduction in any medium, provided the work is properly cited. 